\title{
PENGARUH KOMUNIKASI, IKLIM ORGANISASI DAN GAYA KEPEMIMPINAN TRANSFORMASIONAL KEPALA SEKOLAH TERHADAP KINERJA GURU SMA
}

\author{
Christifora Rahawarin, Suharsimi Arikunto \\ Program Studi Manajemen Pendidikan PPs UNY, Universitas Negeri Yogyakarta \\ irarahawarinrumlus@yahoo.com, ari_uny@hotmail.com
}

\begin{abstract}
Abstrak
Penelitian ini bertujuan untuk mengetahui besarnya pengaruh komunikasi, iklim organisasi, dan kepemimpinan kepala sekolah terhadap kinerja guru. Penelitian ini menggunakan pendekatan kuantitatif dengan metode kausal-komparatif. Populasi dalam penelitian ini adalah seluruh guru SMA di Kabupaten Maluku Tenggara yang berjumlah 276 orang. Jumlah sampel sebanyak 140 guru yang diambil dari 10 sekolah. Teknik pengumpulan data menggunakan kuesioner dengan skala Likert sebagai data primer, wawancara dan observasi sebagai data sekunder. Data dianalisis dengan menggunakan analisis deskriptif, analisis regresi sederhana, dan analisis regresi ganda dengan taraf signifikansi 0,05. Hasil penelitian ini menyimpulkan bahwa: (1) komunikasi organisasi memiliki pengaruh terhadap kinerja guru SMA di Kabupaten Maluku Tenggara; (2) Iklim organisasi berpengaruh terhadap kinerja guru SMA di Kabupaten Maluku; (3) gaya kepemimpinan transformasional kepala sekolah berpengaruh terhadap kinerja guru SMA di Kabupaten Maluku Tenggara; (4)komunikasi organisasi, iklim organisasi, dan gaya kepemimpinan transformasional kepala sekolah secara serentak berpengaruh terhadap kinerja guru SMA di Kabupaten Maluku.

Kata kunci: komunikasi organisasi, iklim organisasi, gaya kepemimpinan transformasional kepala sekolah, kinerja guru

\section{THE EFFECT OF ORGANIZATIONAL, ORGANIZATIONAL CLIMATE, AND PRINCIPAL'S TRANSFORMATIONAL LEADERSHIP STYLE ON THE TEACHER'S PERFORMANCE}

\author{
Christifora Rahawarin, Suharsimi Arikunto \\ Program Studi Manajemen Pendidikan PPs UNY, Universitas Negeri Yogyakarta \\ irarahawarinrumlus@yahoo.com, ari_uny@hotmail.com
}

\begin{abstract}
This study aims to determine the effect of organizational, organizational climate, and principal's transformational leadership style on teachers performance. The study used a quantitative approach with a causal-comparative method. The populations of this study were all teachers of the High Schools in South East Moluccas Distric, they were all 276 teachers. The sample of this study were 140 teachers, taken from 10 schools. Data collection technique used the Likert Scale questionnaires for primary data, interview and observation for secondary data. The data were analyzed using a descriptive analysis, simple regression analysis, and multiple regression analysis.

The results of this study show that: (1) organizational communication has effect on the performance of teachers of the High Schools in South East Moluccas; (2) organizational climate has effect on the performance of teachers of the High Schools in South East Moluccas Distric; (3)Principal's transformational leadeship style has effect on the performance of teachers of the High Schools in South East Moluccas Distric; (4)organizational, organizational climate, and principal's transformational leadership style simultaneously affect the performance of teachers of the High Schools in South East Moluccas Distric.
\end{abstract}

Keywords: organizational communication, organizational climate, principa'sl transformational leadership style, performance of teacher' 


\section{Pendahuluan}

Pendidikan adalah salah satu sendi yang penting dalam kehidupan bermasyarakat, berbangsa, dan bernegara. Pendidikan menduduki posisi penting dalam kegiatan pembangunan karena pendidikan merupakan kegiatan dalam rangka mencerdaskan sumber daya manusia. Hal ini dapat terlihat dalam esensi pendidikan sesuai yang diatur dalam Undang-Undang Nomor 20 Tahun 2003 tentang Sistem Pendidikan Nasional Pasal 1 ayat (1): "Pendidikan adalah proses usaha sadar dan terencana untuk mewujudkan suasana belajar dan proses pembelajaran agar peserta didik secara aktif mengembangkan potensi dirinya untuk memiliki kekuatan spiritual keagamaan, pengendalian diri, kepribadian, kecerdasan, akhlak mulia, serta ketrampilan yang diperluhkan dirinya, masyarakat, bangsa, dan negara".

Pendidikan yang berkualitas akan menghasilkan sumber daya manusia yang berkualitas dan seutuhnya, seperti yang diharapkan oleh undang-undang di atas. Dengan adanya sumber daya manusia yang berkualitas, roda-roda penggerak pembangunan akan lebih cepat bergerak yang pada akhirnya bermuara pada peningkatan kemakmuran seluruh rakyat Indonesia.

Sekolah sebagai salah satu organisasi pendidikan yang merupakan salah satu wadah yang secara langsung untuk mencapai tujuan pendidikan nasional. Sekolah adalah organisasi yang mengelola berbagai sumber daya yang ada seperti, kurikulum, tenaga pendidik, sarana prasarana dan sumber daya lainnya sehingga terjadi saling keterdukungan antarsumber daya yang ada demi tercapainya tujuan pendidikan yang dicita-citakan. Tercapainya tujuan pendidikan yang dicita-citakan, tidak terlepas dari sumber daya guru sebagai kunci utama.

Guru sebagai kunci utama harus benar-benar memahami tugas dan kewajibannya serta menjalankannya dengan baik dalam proses pendidikan di sekolah. Tugas utama guru ialah mendidik, mengajar, membimbing, mengarahkan, melatih, me- nilai, dan mengevaluasi peserta didik. Hal ini sesuai dengan yang diatur dalam UU No.14 Tahun 2005 Pasal 1 ayat (1) Tentang Guru dan Dosen.

Sejatinya, guru adalah bagian integral dari organisasi pendidikan di sekolah secara menyeluruh. Dalam konteks sekolah, guru secara individu maupun secara bersama-sama dengan masyarakat seprofesinya harus didorong untuk menjadi bagian dari organisasi pembelajar melalui keterlibatannya secara sadar dan sukarela serta terus menerus dalam berbagai kegiatan belajar guna mengembangkan profesionalitasnya.

Sebagai suatu profesi, guru harus memiliki berbagai kompetensi yaitu kompetensi pedagogik, kompetensi pribadi, kompetensi profesional, dan kompetensi sosial kemasyarakatan. Hal ini sesuai dengan yang diatur dalam Undang-Undang No. 14 Tahun 2005 Tentang Guru dan Dosen Pasal 10 dikemukakan bahwa kompetensi guru mencakup, kompetensi pedagogis, kompetensi kepribadian, kompetensi sosial, dan kompetensi profesional. Keempat kompetensi tersebut harus benar-benar dipahami serta dapat dikembangkan oleh guru, sehingga dapat menghasilkan proses dan hasil belajar yang berkualitas.

Kinerja guru dapat dilihat dari bagaimana guru menjalankan empat kompetensi tersebut, atau dapat dikatakan aktualisasi dari kompetensi guru dalam menjalankan tugasnya merupakan kinerja guru. Guru dapat berkinerja dengan baik apabila mendapat dukungan yang positif dari lingkungan sekolah dan juga dari pribadi guru sendiri. Guru dalam mengaktualisasikan/mengembangkan berbagai kompetensi di atas tidak terlepas dalam organisasi sekolah.

Sekolah sebagai suatu organisasi tentu saja memiliki dinamika-dinamika organisasi. Berbagai dinamika seperti lingkungan yang selalu berubah dan secara terusmenerus menghadapi berbagai tantangan dan masalah baru membutuhkan harmonisasi organisasi sekolah yang sesuai dengan semangat otonomi dan perberdayaan potensi dan sumber daya pendidikan yang demokratis. 
Pemberdayaan dan pengembangan kompetensi guru di sekolah tidak dapat dilepaskan dari kondisi atau suasana lingkungan yang ada di dalam sebuah organisasi tersebut. Suasana yang nyaman akan sangat mendukung orang untuk dapat mengembangkan potensinya. Iklim organisasi sebagai wujud dari karakteristik lingkungan organisasi yang dirasakan anggota organisasi memiliki peran yang sangat penting bagi kesuksesan organisasi. Hal ini disebabkan iklim organisasi berkaitan erat dengan proses penciptaan suasana dan persepsi yang terbentuk oleh guru terhadap suasana kerja yang kondusif. Suasana kerja yang kondusif diharapkan dapat membantu guru mencapai tujuan lembaga yang pada akhirnya akan meningkatkan kualitas organisasi pada umumnya. De-ngan demikian maka dapat dikatakan kinerja guru pun meningkat.

Salah satu dinamika yang harus mendapat perhatian dalam mengembangkan berbagai kompetensi guru adalah proses komunikasi yang terjadi di dalam organisasi tersebut. Komunikasi diantara manusia adalah suatu proses yang berlangsung ketika seseorang mengeluarkan pesan menggunakan simbol-simbol, tandatanda, dan isyarat-isyarat kontekstual dalam usahanya meng-ekspresikan maksudnya dengan mengirimkan informasi secara tepat sehingga pengertian yang sama dapat dibangun oleh orang lain yang menerima pesan tersebut (Hoy \& Miskel, 2013, p.390).

Komunikasi organisasional adalah suatu proses kolektif dan interaktif yang menciptakan dan menterjemahkan pesanpesan. Aktivitas-aktivitas yang terkoordinasi dengan pertalian hubungan diantara para pelakunya baik didalam maupun di luar organisasi menghasilkan sebuah jaringan kesepahaman. Komunikasi yang baik, terbuka dan lancar antara para guru serta guru dan kepala sekolah diharapkan dapat membantu guru dalam mengembangkan berbagai kompetensi tersebut yang pada akhirnya akan meningkatkan kinerja guru.

Selain dinamika organisasi yang berpengaruh pada kinerja guru seperti yang sudah diuraikan di atas, salah satu faktor yang juga yang menentukan kinerja guru yaitu kepemimpinan kepala sekolah. Kepala sekolah sebagai pemimpin di sekolah harus mampu menjalankan fungsi sebagai pemimpin/leader dan juga manajer agar dapat mencapai sekolah yang berkualitas. Pemimpim/leader lebih mengutamakan faktor manusia, sedangkan manajer lebih kepada hal-hal yang tidak terkait dengan manusia, misalnya administratif.

Kepala sekolah harus mampu menjadi panutan bagi guru dan juga semua warga sekolah lainnya. Kepala sekolah harus bisa mengenal dengan baik setiap bawahannya (guru), sehingga bisa menggunakan pendekatan/cara yang tepat dalam mengambil tindakan dalam rangka meningkatkan kinerja guru. Gaya kepemimpinan transformasional, dimana kepala sekolah mampu bersama-sama dengan guru merumuskan visi, misi, dan tujuan sekolah serta mampu mendorong warga sekolah untuk melaksanakannya. Kepala sekolah menjadi panutan, dikagumi, dan dipercaya oleh warga sekolah. Kepala sekolah mampu memotivasi guru dan untuk berprestasi serta inovatif dan kreatif. Dengan demikian gaya kepemimpinan transformasional diharapkan dapat meningkatkan kinerja guru. Kepala sekolah pun harus mampu mengambil keputusan yang tepat dalam berbagai situasi demi kepentingan sekolah dan siswa. Kepala sekolah yang mampu mengerti para guru, serta menggunakan gaya kepemimpinan yang tepat sesuai dengan situasi dan keadaan diharapkan dapat membantu guru dalam mengembangkan kompetensinya yang pada akhirnya dapat meningkatkan kinerja guru.

Kebanyakan guru cenderung malas untuk belajar dan mengembangkan kompetensinya, sehingga berimplikasi terhadap menurunnya kinerja guru. Hal ini bisa dikarenakan rendahnya motivasi diri dan komitmen dalam pekerjaan sebagai seorang guru. Dalam pikiran guru yang penting bahwa tiap hari ke sekolah dan mengajar, dan juga bahwa pekerjaan sebagai guru merupakan pilihan terakhir karena sudah tidak ada pilihan yang lain. 
Hal-hal di atas tentunya sangat bertentangan dengan yang diatur dalam UU No. 14 Tahun 2005 Tentang Guru dan Dosen Pasal 7 ayat (1) bahwa "profesi guru merupakan bidang pekerjaan khusus yang dilaksanakan berdasarkan prinsip memiliki bakat, minat, panggilan jiwa, idealisme, komitmen dan memiliki tanggung jawab". Selain itu kurang adanya perhatian dari pemerintah daerah dalam memberikan pelatihan kepada para guru sehingga dapat meningkatkan kinerja guru.

Semua dinamika organisasi di atas haruslah dikelola agar dapat menjadi penggerak kemajuan organisasi dan bukannya malah menghambat perkembangan organisasi atau menjadi masalah dalam organisasi. Berbagai problematika dalam organisasi yang umum terjadi: masalah komunikasi yang tidak lancar, konflik antar anggota, konflik antar kelompok, perilaku individu yang tidak sesuai dengan nilai organisasi, iklim organisasi yang tertutup, gaya kepemimpinan kepala sekolah yang kurang memotivasi bawahannya, kurang dapat dipercaya, kurang menstimulus bawahannya agar inovatif dan kreatif, kurang mempertimbangakan kebutuhan individu guru, serta kinerja anggota yang belum memuaskan, dan produktivitas organisasi rendah.

Problematika organisasi secara umum dijumpai pada berbagai organisasi pendidikan, termasuk juga dijumpai pada sekolah SMA di Kabupaten Maluku Tenggara. Dimana komunikasi antar guru, dan antar guru dan kepala sekolah kurang efektif, serta iklim sekolah yang tertutup dan tidak sehat. Gaya kepemimpinan kepala sekolah yang kurang memperhatikan kebutuhan guru untuk berprestasi, kurang memotivasi warga sekolah untuk mencapai visi, misi, dan tujuan sekolah. Semuanya itu menjadi faktor dalam menentukan kinerja guru. Berdasarkan uraian di atas, penulis sengaja mengambil judul penelitian "Pengaruh Komunikasi Organisasi, Iklim Organisasi, dan Gaya Kepemimpinan Transformasional Kepala Sekolah terhadap Kinerja Guru SMA di Kabupaten Maluku Tenggara".
Adapun permasalahan yang diteliti ialah: (1) komunikasi organisasi pada SMA di Kabupaten Maluku Tenggara yang kurang efektif. (2) iklim organisasi pada SMA di Kabupaten Maluku Tenggara kurang yang kondusif. (3) gaya kepemimpinan transformasional kepala sekolah SMA di Kabupaten Maluku Tenggara yang belum sesuai dengan indikator-indikatornya. (4) kinerja guru SMA di Kabupaten Maluku Tenggara yang belum optimal.

Secara umum, penelitian ini bertujuan untuk mengetahui gambaran empiris ada tidaknya pengaruh komunikasi organisasi, iklim organisasi, dan kepemimpinan kepala sekolah SMA di Kabupaten Maluku Tenggara. Secara khusus, penelitian ini bertujuan untuk mengetahui dan menganalisis: (1) pengaruh komunikasi organisasi terhadap kinerja guru SMA di Kabupaten Maluku Tenggara; (2) pengaruh iklim organisasi terhadap kinerja guru SMA di Kabupaten Maluku Tenggara; (3) pengaruh gaya kepemimpinan transformasional kepala sekolah terhadap kinerja guru SMA di Kabupaten Maluku Tenggara; (4) pengaruh komunikasi organisasi, iklim organisasi, dan gaya kepemimpinan transformasional kepala sekolah terhadap kinerja guru SMA di Kabupaten Maluku Tenggara.

Penelitian ini diharapkan dapat memberikan manfaat baik bagi pihak peneliti dan SMA di Kabupaten Maluku Tenggara maupun bagi pengembangan ilmu pengetahuan (akademik). Adapun manfaat teoretis penelitian ini adalah Menambah ilmu pengetahuan terutama yang berhubungan dengan ilmu manajemen pendidikan secara umum dan komunikasi organisasi, iklim organisasi, serta gaya kepemimpinan kepala sekolah, selain itu menjadi bahan masukan bagi pihak-pihak yang berkepentingan dalam penelitian lanjutan terhadap objek sejenis atau aspek lainnya yang belum tercakup dalam penelitian ini.

Manfaat Praktis penelitian ini adalah sebagai berikut memberikan informasi bagi pihak sekolah tingkat SMA di Kabupaten Maluku Tenggara dalam usaha memperbaiki dan meningkatkan komunikasi organisasi, iklim organisasi, dan gaya kepe- 
mimpinan kepala sekolah. Selain itu, memberikan pengetahuan bagi pemangku kepentingan, yaitu guru dan kepala sekolah di sekolah tingkat SMA Kabupaten Maluku Tenggara mengenai perbaikan pengelolaan komunikasi organisasi, iklim organisasi serta gaya kepemimpinan kepala sekolah yang pada akhirnya mampu mempengaruhi kinerja guru.

\section{Metode Penelitian}

Jenis, Waktu, dan Tempat Penelitian

Penelitian ini merupakan penelitian yang bersifat ex-post facto. Tidak ada perlakuan apapun terhadap variabel oleh peneliti. Penelitian menggunakan pendekatan kuantitatif yang bersifat korelasional untuk menjelaskan hubungan asosiatif antara variabel bebas dengan variabel terikat. Penelitian dilaksanakan pada SMA di Kabupaten Maluku Tenggara dan dilaksanakan selama dua bulan yaitu bulan Maret sampai April 2014.

\section{Populasi dan Sampel Penelitian}

Populasi penelitian ialah semua guru SMA di Kabupaten Maluku Tenggara dengan jumlah 12 SMA dengan 6 Kecamatan. Jumlah populasi guru SMA di Kabupaten Maluku Tenggara yaitu 276 guru. Teknik pengambilan sampel dengan menggunakan Cluster Sampling (area sampling/sampling daerah). Area/daerah terbagi menjadi dua yaitu daerah (pulau) Kei Kecil dan daerah (pulau) Kei Besar. Kei Besar terdapat tiga kecamatan, dan setiap kecamatan masingmasing diambil satu sekolah kemudian diambil sampel (guru) dari masing-masing sekolah tersebut. Kei Kecil terdiri dari tiga kecamatan dan terdapat enam SMA. Sampel diambil dari semua SMA yang ada. Alasannya bahwa jumlah guru SMA di Kei Kecil banyak, sedangkan jumlah guru SMA di Kei Besar sangat sedikit. Sampel penelitian adalah 140 guru. Penentuan sampel ini dengan menggunakan tabel Kretjcie dan Morgan dengan taraf signifikansi $5 \%$.

Variabel Penelitian

Variabel dalam penelitian ini ialah komunikasi organisasi (X1), iklim organisa- si (X2), dan kepemimpinan kepala sekolah (X3) sebagai variabel bebas dan kinerja guru (Y) sebagai variabel terikat.

Definisi operasional komunikasi organisasi ialah proses penyampaian informasi/pesan dari pengirim ke penerima dalam rangka pengaliran informasi verbal dan non verbal di dalam organisasi baik secara vertikal, horizontal, dan diagonal dimana informasi tersebut dapat dipahami bersama serta mempengaruhi perilaku mereka. Dimensi komunikasi organisasi yang digunakan dalam penelitian ini mengacu pada teori aliran komunikasi oleh Robbins dan Ivancevich yang mengalir secara vertikal, horizontal, dan diagonal.

Definisi operasioanal iklim organisasi ialah persepsi perasaan anggota organisasi terhadap berbagai aspek sosial dan psikologis organisasi yang mempengaruhi karakteristik anggota untuk berperilaku tertentu. Dimensi iklim organisasi yang digunakan di dalam penelitian ini dikembangkan dari dimensi iklim organisasi Hoy \& Miskel serta Wirawan, yakni keterbukaan, kesehatan, dan kewarganegaraan, serta lingkungan fisik.

Kepemimpinan adalah kemampuan yang dimiliki pemimpin untuk mempengaruhi, menggerakan, dan mengarahkan yang dipimpin agar mereka mau dan dapat melaksanakan tugas-tugas yang dibebankan kepadanya untuk mencapai tujuan. Kepemimpinan transformasional kepala sekolah ialah kepemimpinan kepala sekolah yang mampu memotivasi guru, mampu menstimulus guru agar kreatif, mempertimbangkan kebutuhan guru, dan tampil sebagai pribadi yang berkarisma.

Untuk mengukur variabel kepemimpinan kepala sekolah, peneliti menggunakan gaya kepemimpinan transformasional dengan lima komponen yang dikembangkan oleh Bass dan Avolio seperti yang dikutip oleh Hoy \& Miskel, yaitu: (1) Charisma (2) idealized influence, (3) intellectual stimulation, (4) individualized consideration, dan (5) inspirationan motivation.

Definisi operasional kinerja guru ialah deskripsi perilaku yang menunjukan unjuk kerja dari kemampuan untuk me- 
lakukan tugas atau profesi guru dan berbagai perilaku dan sifat pribadi yang diperluhkan untuk menunjang profesinya sebagai guru. Kinerja guru yang dimaksud dalam penelitian ini yaitu bentuk aktualisasi dari kompetensi-kompetensi guru. Dimensi kerja guru yang digunakan dalam penelitian ini yaitu empat kompetensi guru yaitu, kompetensi kepribadian, kompetensi pedagogik, kompetensi profesional, dan kompetensi sosial.

Teknik dan Instrumen Pengumpulan Data

Teknik pengumpulan data dengan menggunakan metode angket/kuesioner sebagai data primer, sedangkan wawancara dan pengamatan sebagai data sekunder atau data pendukung. Instrumen penelitian (angket) dikembangkan berdasarkan dimensi-dimensi variabel penelitian dan indikator-indikatornya.

Validitas dan Reliabilitas Instrumen

Instrumen disebut valid jika mengukur apa yang seharusnya diukur. Dalam penelitian ini bentuk instrumen yang digunakan yaitu bentuk instrumen angket sebagai data primer/utama. Angket diujicobakan pada guru yang tidak termasuk dalam sampel penelitian. Uji coba validitas dilaksanakan pada SMA Negeri 1 Kei Kecil dengan jumlah responden sebanyak 40 guru. Uji validitas instrumen menggunakan koefisien korelasi produk momen dari Karl Pearson. Pengujian validitas instrumen dengan menggunakan bantuan SPSS 16.0. dengan taraf signifikansi 0,05 . Apabila nilai sig. kurang dari 0,05 maka butir tersebut dikatakan valid. Jika nilai sig. lebih dari 0,05 maka butir instrumen tersebut dikatakan tidak valid dan dibuang/diganti.

"Reliabilitas menunjuk pada suatu pengertian bahwa sesuatu instrumen cukup dapat dipercaya untuk digunakan sebagai alat pengumpul data karena instrumen tersebut sudah cukup baik" (Arikunto, 2006, p.178). Instrumen dikatakan reliabel jika memberikan hasil yang sama jika digunakan untuk mengukur hal yang sama pada waktu dan tempat yang berbeda. Biasanya jika indeks reliabilitas $\geq 0,7$ maka instrumennya dapat dipakai untuk melakukan pengukuran. Pengujian reliabilitas intrumen dengan menggunakan bantuan SPSS 16.0.

Teknik Analisis Data

Penyeleksian dan Pengklarifikasian Data

Lembar angket yang diisi responden diperiksa kelengkapan pengisiannya kemudian disortir, kemudian diinputkan dan diklarifikasikan ke dalam tabulasi data.

Analisis Deskripsi Karakteristik Responden dan Variabel

Data yang telah ditabulasi kemudian dianalisis sehingga didapatkan deskripsi umum baik dari karakteristik responden penelitian maupun variabel penelitian. Analisis karakteristik responden dan variabel dilakukan secara deskriptif kuantitatif bertujuan untuk memberikan gambaran awal mengenai karakteristik responden yang terlibat dan variabel-variabel yang dihipotesiskan.

Analisis deskripsi variabel dilakukan dengan cara menghitung, menyajikan karakteristik kuantitatif tiap variabel yakni ukuran tendensi, standar deviasi, rerata (Mean), maksimum, dan minumum, persentase ketercapaian dan juga kategori.

Kategori dihitung dan dikelompokkan menggunakan rumus Azwar (2007, 109) sebagai berikut.

$$
\begin{array}{ll}
X<(\mu-1,5 \partial) & \text { kategori rendah } \\
(\mu-1,5 \partial) \leq X<(\mu+1,5 \partial) & \text { kategori sedang } \\
(\mu+1,5 \partial) \leq X & \text { kategori tinggi }
\end{array}
$$

Keterangan:

$\mu=$ rata-rata ideal yaitu $0,5 \times$ (nilai terendah + nilai tertinggi)

$\partial=1 / 6$ (nilai tertinggi - nilai terendah)

Uji persyaratan Analisis

\section{Uji normalitas}

Uji ini digunakan untuk mengetahui apakah data yang diperoleh berdistribusi normal atau tidak normal. Dalam penelitian ini, uji normalitas yang digunakan adalah uji K smigorof dengan taraf signifikansi 5\%. Analisis data dilakukan dengan bantuan SPSS 16.0. Data berdistribusi normal 
jika nilai Asymp.sig. lebih dari 0,05. Hasil uji menunjukkan data berdistribusi normal.

\section{Uji linearitas}

Uji linearitas digunakan untuk mengetahui data yang diperoleh linear atau tidak. Analisis uji Linearitas dengan menggunakan bantuan SPSS 16.0. Hasil uji linearitas menunjukan bahwa hubungan antara masing-masing variabel bebas $(\mathrm{X} 1, \mathrm{X} 2, \mathrm{X} 3)$ dengn variabel terikat $(Y)$ semuanya linear.

\section{Uji multikolinearitas}

Uji multikolinearitas dilakukan untuk mengetahui apakah terjadi korelasi antarvariabel bebas atau tidak. Model regresi linear ganda yang baik mensyaratkan tidak terjadi korelasi yang tinggi antara variabelvariabel bebas. Pendekatan multikolinearitas dilakukan dengan melakukan colinearty diagnostics dengan bantuan SPSS 16.0. kriteria yang digunakan adalah jika nilai VIF $<10$ pada output SPSS 16.0 maka dinyatakan tidak terjadi multikolinearitas.

Uji heteroskedastisitas

Uji heteroskedastisitas dilakukan untuk mengetahui apakah terjadi heteroske- dastisitas yang tidak diinginkan dalam model regresi linear. Model regresi yang baik mensyaratkan adanya keseragaman variansi residu variabel bebas pada model regresi yang disebut kondisi homoskedastisitas, sedangkan bila variansi residu variabel bebas tidak seragam maka kondisi ini disebut heteroskedastisitas.

\section{Uji Hipotesis}

Pengujian hipotesis dengan menggunakan analisis regresi linear sederhana dan analisis regresi linear ganda. Analisis regresi linear sederhana digunakan untuk menguji ada tidaknya pengaruh antar satu variabel bebas dan variabel terikat. Sedangkan analisis regresi linear ganda digunakan untuk menguji ada atau tidaknya pengaruh antar dua atau lebih variabel secara bersama-sama terhadap satu variabel terikat. Proses analisis data dilakukan dengan bantuan software SPSS 16.0. Apabila output pada SPSS 16.0 menunjukan signifikan < 0,05 (sesuai dengan taraf signifikansi yang digunakan dalam uji hipotesis) maka simpulannya terdapat pengaruh yang signifikan.

\section{Hasil Penelitian dan Pembahasan}

Deskripsi Hasil Penelitian

Tabel 1. Deskripsi Data Hasil Penelitian

\begin{tabular}{lccccc}
\hline \multicolumn{1}{c}{ Ket. Kinerja } & $\begin{array}{c}\text { Komunikasi } \\
\text { Organisasi } \\
\text { Jumlah Skor }\end{array}$ & $\begin{array}{c}\text { Iklim } \\
\text { Organisasi }\end{array}$ & $\begin{array}{c}\text { Kepemimpinan } \\
\text { Kepala Sekolah }\end{array}$ & $\begin{array}{c}\text { Kinerja guru } \\
(\mathrm{X} 2)\end{array}$ & $\begin{array}{c}\text { Kinerja } \\
\text { guru SMA }\end{array}$ \\
\hline Skor Rata-rata & 7030 & 14357 & 14129 & 28258 & 28258 \\
Skor Ideal & 50,21 & 102,55 & 100,92 & 201,84 & 201,84 \\
Persentase Ketercapaian & 8960 & 18480 & 17360 & 34720 & 34720 \\
Kategori & $78,46 \%$ & $77,69 \%$ & $81,39 \%$ & $81,39 \%$ & $81,39 \%$ \\
\hline
\end{tabular}

Jumlah skor merupakan skor nilai setiap guru yang dijumlahkan berdasarkan instrumennya. Skor rata-rata diperoleh dari jumlah skor tiap intrumen dibagi dengan seluruh guru/responden (140). Skor ideal merupakan skor tertinggi yang dapat dicapai, diperoleh dari jumlah butir/soal dikali skala tertinggi(4) dikali guru(140).
Instrumen komunikasi organisasi berjumlah 16 butir, instrumen iklim organisasi berjumlah 33 butir, instrumen kepemimpinan kepala sekolah 31 butir, dan kinerja guru 62 butir. Persentase ketercapaian yaitu jumlah skor dibagi skor ideal dikali $100 \%$. Sedangkan jenis kategori didasarkan pada hasil skor rata-rata setiap variabel. 
Komunikasi Organisasi (X1).

Tabel 2. Statistik Deskriptif X1

\begin{tabular}{lcc}
\hline $\mathrm{N}$ & Valid & 140 \\
& Missing & 0 \\
\hline Mean & & 50,21 \\
Median & 50,00 \\
Mode & 48 \\
Std. Deviation & 4,198 \\
Variance & 17,623 \\
Range & 24 \\
Minimum & 40 \\
Maksimum & 64 \\
Sum & 7030 \\
\hline
\end{tabular}

Tabel 3. Distribusi Frekuensi Komunikasi Organisasi (X1)

\begin{tabular}{ccc}
\hline $\begin{array}{c}\text { Interval Skor } \\
\text { Total X1 }\end{array}$ & Frekuensi & $\%$ \\
\hline $39-41$ & 2 & 1,4 \\
$42-44$ & 7 & 5 \\
$45-47$ & 27 & 19,3 \\
$48-50$ & 47 & 33,6 \\
$51-53$ & 30 & 21,4 \\
$54-56$ & 17 & 12,1 \\
$57-59$ & 4 & 2,9 \\
$60-62$ & 4 & 2,9 \\
$63-65$ & 2 & 1,4 \\
Jumlah & 140 & 100 \\
\hline
\end{tabular}

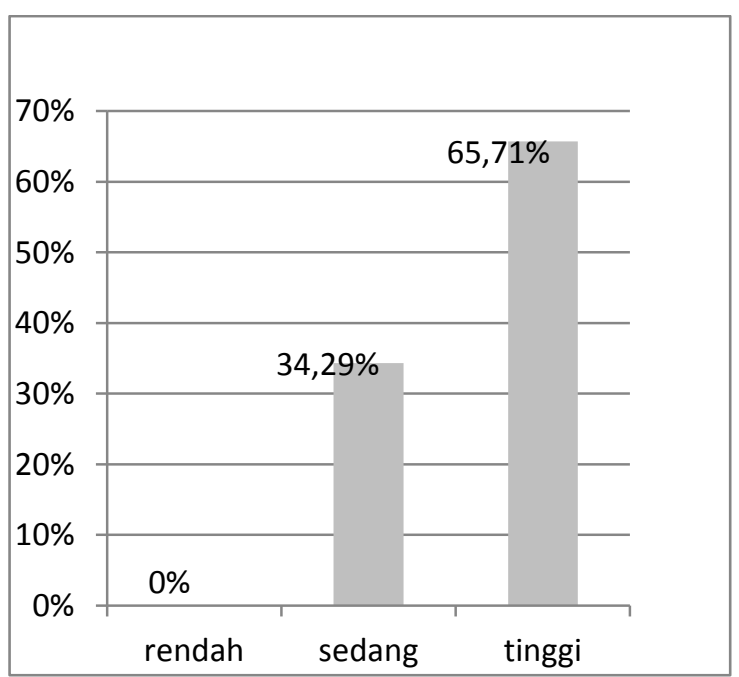

Gambar 1. Persentase Kategori Komunikasi Organisasi (X1)
Iklim Organisasi (X2).

Tabel 4. Statistik Deskriptif X2

\begin{tabular}{lcc}
\hline $\mathrm{N}$ & Valid & 140 \\
& Missing & 0 \\
\hline Mean & & 102,55 \\
Median & 102,00 \\
Mode & 100 \\
Std. Deviation & 11,099 \\
Variance & 123,185 \\
Range & 61 \\
Minimum & 71 \\
Maksimum & 132 \\
Sum & 14357 \\
\hline
\end{tabular}

Tabel 5. Distribusi Frekuensi X2

\begin{tabular}{ccc}
\hline $\begin{array}{c}\text { Interval Skor } \\
\text { Total X1 }\end{array}$ & Frekuensi & $\%$ \\
\hline $71-77$ & 2 & 1,4 \\
$78-84$ & 5 & 3,6 \\
$85-91$ & 14 & 10 \\
$92-98$ & 24 & 17,1 \\
$99-105$ & 39 & 27,9 \\
$106-112$ & 39 & 27,9 \\
$113-119$ & 6 & 4,3 \\
$120-126$ & 6 & 4,3 \\
$127-133$ & 5 & 3,6 \\
Jumlah & 140 & 100 \\
\hline
\end{tabular}

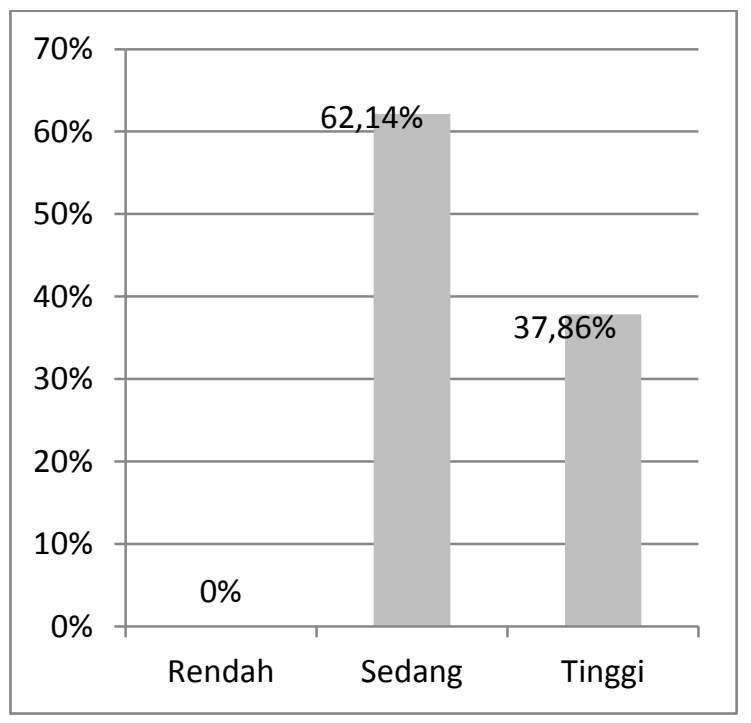

Gambar 2. Persentase Kategori Iklim Organisasi (X2) 
Gaya Kepemimpinan Transformasional Kepala Sekolah (X3)

Tabel 6. Statistik Deskriptif X3

\begin{tabular}{lcc}
\hline $\mathrm{N}$ & Valid & 140 \\
& Missing & 0 \\
\hline Mean & & 101,37 \\
Median & 102,00 \\
Mode & 93 \\
Std. Deviation & 14,976 \\
Variance & 224,293 \\
Range & 63 \\
Minimum & 61 \\
Maksimum & 124 \\
Sum & 14192 \\
\hline
\end{tabular}

Tabel 7. Distribusi Frekuensi X3

\begin{tabular}{ccc}
\hline $\begin{array}{c}\text { Interval Skor Total } \\
\text { Kepemimpinan } \\
\text { Trans. KS. }\end{array}$ & Frekuensi & $\%$ \\
\hline $59-66$ & 3 & 2,1 \\
$67-74$ & 2 & 1,4 \\
$75-82$ & 15 & 10,7 \\
$83-90$ & 7 & 5 \\
$91-98$ & 39 & 27,9 \\
$99-106$ & 17 & 12,1 \\
$107-114$ & 25 & 17,9 \\
$115-122$ & 22 & 15,7 \\
$123-130$ & 10 & 7,1 \\
Jumlah & 140 & 100 \\
\hline
\end{tabular}

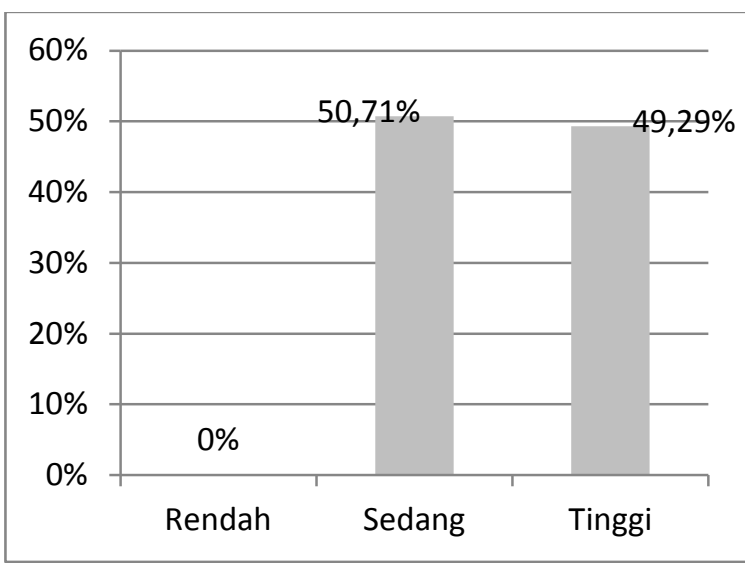

Gambar 3. Persentase Kategori Gaya Kepemimpinan Transformasional Kepala Sekolah (X3)
Kinerja Guru (Y)

Tabel 8. Statistik Deskriptif Y

\begin{tabular}{lcc}
\hline $\mathrm{N}$ & Valid & 140 \\
& Missing & 0 \\
\hline Mean & & 201.84 \\
Median & 201.50 \\
Mode & 211 \\
Std. Deviation & 19,096 \\
Variance & 363,165 \\
Range & 73 \\
Minimum & 172 \\
Maksimum & 245 \\
Sum & 28258 \\
\hline
\end{tabular}

Tabel 9. Distribusi Frekuensi Y

\begin{tabular}{ccc}
\hline $\begin{array}{c}\text { Interval Skor Total } \\
\text { Kinerja Guru }\end{array}$ & Frekuensi & $\%$ \\
\hline $170-178$ & 13 & 9,28 \\
$179-187$ & 27 & 19,28 \\
$188-196$ & 23 & 16,43 \\
$197-205$ & 19 & 13,57 \\
$206-214$ & 22 & 15,71 \\
$215-223$ & 11 & 7,86 \\
$224-232$ & 17 & 12,14 \\
$233-241$ & 4 & 2,86 \\
$242-250$ & 4 & 2,86 \\
Jumlah & 140 & 100 \\
\hline
\end{tabular}

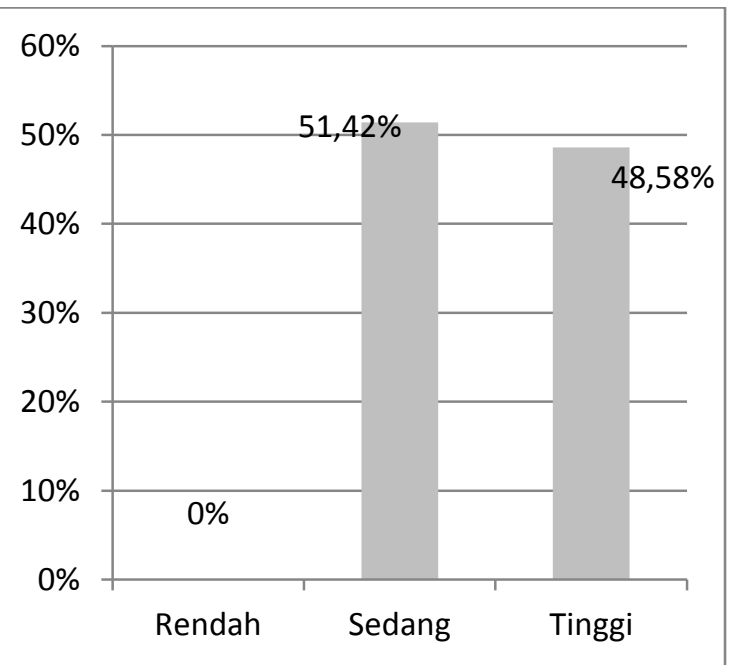

Gambar 4. Persentase Kategori Kinerja Guru (Y) 


\section{Hasil Uji Hipotesis}

Dalam penelitian ini dilakukan empat pengujian hipotesis dengan uji regresi linear sederhana untuk masing-masing variabel independen terhadap variabel dependen, dan uji regresi linear ganda untuk ketiga variabel independen terhadap variabel dependen. Dalam uji regresi ini juga akan dilihat besarnya koefisien korelasi yang menunjukan seberapa besar hubungan yang terjadi antara variabel independen dan variabel dependen.

\section{Pengujian Hipotesis Pertama.}

Uji hipotesis pertama menggunakan uji regresi linear sederhana antara variabel independen komunikasi organisasi (X1) dengan variabel dependen kinerja guru (Y). Hipotesisnya (H1) ialah Komunikasi organisasi berpengaruh terhadap kinerja guru. Kriteria yang digunakan ialah $\mathrm{H} 1 \mathrm{di}-$ terima jika nilai sign $<0,05$. Hasil uji regresi dengan menggunakan program SPSS 16,0 disajikan pada Tabel 10.

Tabel 10. Hasil Analisis Regresi Linear Sederhana X1 dan Y

R Adjusted Std. Error of Model R Square R Square the Estimate

\begin{tabular}{lllll}
\hline 1 & $.475^{\mathrm{a}}$ & .226 & .220 & 16.840 \\
\hline
\end{tabular}

a. Predictors: (Constant), Komunikasi Organisasi

Hasil analisis regresi menemukan koefisien korelasi (R) sebesar 0,475 . Hal ini menunjukan bahwa terdapat hubungan yang positif dengan kategori sedang antara komunikasi organisasi dengan kinerja guru. Koefisien adjusted $\mathrm{R}^{2}$ sebesar $22 \%$. Hal ini menunjukan bahwa komunikasi organisasi menyumbang 22\% terhadap kinerja guru. Hasil analisis regresi juga menemukan bahwa nilai $\mathrm{F}=40,237$ dan signifikan $\mathrm{p}(\mathrm{sig})<0,05$. Hal ini berarti H1 diterima, jadi dapat disimpulkan komunikasi organisasi mempengaruhi kinerja guru.

\section{Pengujian Hipotesis Kedua}

Uji hipotesis kedua menggunakan uji regresi linear sederhana antara variabel independen iklim organisasi (X2) dengan variabel dependen kinerja guru $(\mathrm{Y})$. Hipotesisnya $(\mathrm{H} 1)$ ialah Iklim organisasi berpengaruh terhadap kinerja guru. Kriteria yang digunakan ialah $\mathrm{H} 1$ diterima jika nilai sign $<0,05$. Hasil uji regresi dengan menggunakan program SPSS 16.0. disajikan pada Tabel 11.:

Tabel 11. Hasil Analisis Regresi Linear Sederhana X2 dan Y

$\mathrm{R}$ Adjusted Std. Error of Model R Square R Square the Estimate

\begin{tabular}{lllll}
\hline 1 & $.592^{\mathrm{a}}$ & .350 & .345 & 15.427 \\
\hline
\end{tabular}

a. Predictors: (Constant), Iklim Organisasi

Hasil analisis regresi menemukan koefisien korelasi (R) sebesar 0,592. Hal ini menunjukan bahwa terdapat hubungan yang positif dengan kategori sedang antara iklim organisasi dengan kinerja guru. Koefisien adjusted $\mathrm{R}^{2}$ sebesar $34,5 \%$. Hal ini menunjukan bahwa iklim organisasi menyumbang 34,5\% terhadap kinerja guru. Hasil analisis regresi juga menemukan bahwa $F=74,375$ dan signifikan $p($ sig $)<0,05$. Hal ini berarti $\mathrm{H} 1$ diterima, jadi dapat disimpulkan bahwa iklim organisasi mempengaruhi kinerja guru.

\section{Pengujian Hipotesis Ketiga}

Uji hipotesis ketiga menggunakan uji regresi linear sederhana antara variabel independen gaya kepemimpinan transformasional kepala sekolah organisasi (X3) dengan variabel dependen kinerja guru (Y). Hipotesisnya (H1) ialah: Gaya kepemimpinan transformasional kepala sekolah berpengaruh terhadap kinerja guru. Kriteria yang digunakan ialah $\mathrm{H} 1$ diterima jika nilai sign $<0,05$. Hasil uji regresi dengan menggunakan program SPSS 16.0 disajikan pada Tabel 12 .

Tabel 12. Hasil Analisis Regresi X3 dan Y

$\mathrm{R}$ Adjusted Std. Error of Model R Square R Square the Estimate

\begin{tabular}{lllll}
\hline 1 & $.755^{\mathrm{a}}$ & .570 & .561 & 12.640 \\
\hline
\end{tabular}

a. Predictors: (Constant), Kepemimpinan Kepala Sekolah, Komunikasi Organisasi, Iklim Organisasi 
Hasil analisis regresi menemukan koefisien korelasi (R) sebesar 0,706. Hal ini menunjukan bahwa terdapat hubungan yang positif dan kuat antara gaya kepemimpinan transformasional kepala sekolah terhadap kinerja guru. Koefisien adjusted $\mathrm{R}^{2}$ sebesar $49,4 \%$. Hal ini menunjukan bahwa kepemimpinan kepala sekolah menyumbang $49,4 \%$ terhadap kinerja guru. Hasil analisis regresi juga menemukan bahwa $F=136,925$ dan signifikan $p($ sig) < 0,05 . Hal ini berarti H1 diterima, jadi dapat disimpulkan bahwa gaya kepemimpinan transformasional kepala sekolah mempengaruhi kinerja guru.

\section{Pengujian Hipotesis Keempat}

Uji hipotesis keempat menggunakan uji regresi linear ganda antara variabel independen komunikasi organisasi (X1), iklim organisasi (X2), dan gaya kepemimpinan transformasional kepala sekolah organisasi (X3) dengan variabel dependen kinerja guru $(\mathrm{Y})$. Hipotesisnya (H1) ialah komunikasi organisasi, iklim organisasi, dan gaya kepemimpinan transformasional kepala sekolah secara bersama-sama berpengaruh terhadap kinerja guru. Kriteria yang digunakan ialah $\mathrm{H} 1$ diterima jika nilai sign $<0,05$. Hasil uji regresi dengan menggunakan program SPSS 16.0 disajikan pada Tabel 13.

Tabel 13. Hasil Analisi Regresi Ganda X1, X2, dan X3 terhadap Y

R Adjusted Std. Error of Model R Square R Square the Estimate

\begin{tabular}{lllll}
\hline 1 & $.706^{\mathrm{a}}$ & .498 & .494 & 13.559
\end{tabular}

a. Predictors: (Constant), Kepemimpinan Kepala Sekolah

Hasil analisis regresi ganda di atas menemukan koefisien korelasi ganda (R) sebesar 0,755 . Hal ini menunjukkan bahwa terdapat hubungan yang positif dan kuat antara komunikasi organisasi, iklim organisasi dan gaya kepemimpinan transformasional kepala sekolah terhadap kinerja guru. Koefisien adjusted $\mathrm{R}^{2}$ sebesar $56,1 \%$. Hal ini menunjukan bahwa komunikasi organisasi, iklim organisasi, dan gaya kepemimpinan transformasional kepala sekolah menyumbang $56,1 \%$ terhadap kinerja guru. Hasil analisis regresi juga menemukan bahwa $F=60,115$ dan signifikan $p($ sig) $<0,05$. Hal ini berarti H1 diterima, jadi dapat disimpulkan bahwa komunikasi organisasi, iklim organisasi, dan gaya kepemimpinan transformasional kepala sekolah secara bersama-sama mempengaruhi kinerja guru.

Hasil analisis regresi dengan SPSS 16.0 juga memperoleh koefisien dalam persamaan garis regresi sebagai berikut.

$\mathrm{Y}=\mathrm{a}_{0}+\mathrm{a}_{1} \mathrm{X} 1+\mathrm{a}_{2} \mathrm{X} 2+\mathrm{a}_{3} \mathrm{X} 3$

$Y=57,103+0,180 X 1+0,221 X 2+0,501 X 3$

dimana :

Y : Kinerja guru SMA di Kab. Maluku Tenggara

X1 : Komunikasi Organisasi

$\mathrm{X} 2$ : Iklim Organisasi

X3 : Gaya kepemimpinan trans. Kepala Sekolah

Persamaan garis regresi di atas dapat diinterprestasikan sebagai berikut: konstanta sebesar 57,103 artinya jika komunikasi organisasi (X1), iklim organisasi (X2), dan gaya kepemimpinan transformasional kepala sekolah (X3) nilainya 0, maka kinerja guru bernilai 57,103. Besarnya konstanta 57,103 ini jika dibandingkan dengan skor total kinerja guru $(\mathrm{Y})$ yang diperoleh yaitu 28258, diperoleh persentase sebesar $0,2 \%$. Ini berarti kinerja guru tanpa adanya variabel $\mathrm{X} 1, \mathrm{X} 2$, dan $\mathrm{X} 3$ (seandainya ketiganya bernilai nol) bernilai sangat kecil yaitu sebesar 57,103 atau 0,2\%.

Koefisien regresi variabel komunikasi organisasi (X1) sebesar 0,180 artinya jika variabel independen lainnya (iklim organisasi dan gaya kepemimpinan transformasional kepala sekolah) nilainya tetap, dan komunikasi organisasi mengalami kenaikan $1 \%$, maka kinerja guru akan mengalami kenaikan sebesar 0,180. Hubungan yang terjadi adalah hubungan positif, artinya semakin naik komunikasi organisasi semakin naik pula kinerja guru.

Koefisien regresi variabel iklim organisasi (X2) sebesar 0,221 artinya jika variabel independen lainnya (komunikasi organisasi dan gaya kepemimpinan trans- 
formasional kepala sekolah) nilainya tetap, dan iklim organisasi mengalami kenaikan $1 \%$, maka kinerja guru akan mengalami kenaikan sebesar 0,221. Hubungan yang terjadi adalah hubungan positif, artinya semakin naik iklim organisasi semakin naik pula kinerja guru.

Koefisien regresi variabel gaya kepemimpinan transformasional kepala sekolah (X3) sebesar 0,501 artinya jika variabel independen lainnya (komunikasi organisasi dan iklim organisasi) nilainya tetap, dan gaya kepemimpinan transformasional kepala sekolah mengalami kenaikan 1\%, maka kinerja guru akan mengalami kenaikan sebesar 0,501. Hubungan yang terjadi adalah hubungan positif, artinya semakin naik gaya kepemimpinan transformasional kepala sekolah semakin naik pula kinerja guru. Dengan demikian dapat dilihat bahwa hubungan ketiga variabel independen terhadap variabel dependen semuanya merupakan hubungan positif.

Pembahasan

Penelitian ini mengungkapkan pengaruh komunikasi organisasi, iklim organisasi dan gaya kepemimpinan transformasional kepala sekolah terhadap kinerja guru SMA di kabupaten Maluku Tenggara. Hasil analisis dibahas sebagai berikut.

Berdasarkan hasil deskriptif pada variabel kinerja guru, diperoleh bahwa menurut persentase kategorinya, responden yang termasuk dalam kategori tinggi $48,58 \%$, sedangkan yang berkategori sedang $51,42 \%$, dan yang berkategori rendah $0 \%$ atau tidak ada sama sekali. Selain itu diperoleh juga jumlah skor total kinerja guru yang dicapai oleh 140 responden/ guru sebesar 28258. Persentase ketercapaian kinerja guru SMA di kabupaten Maluku Tenggara sebesar $81,39 \%$. Masih 18,61 yang belum terpenuhi. Selain itu rata-rata skor kinerja guru adalah sebesar 201,84 dan secara umum kinerja guru SMA di kabupaten Maluku Tenggara ada pada kategori sedang.

Hasil perhitungan menunjukkan bahwa sebagian besar guru SMA di kabupaten Maluku Tenggara memiliki kinerja yang baik. Hal tersebut juga didukung dengan hasil wawancara dan pengamatan kinerja guru, dimana dalam proses pembelajaran guru mengelolah kelas dengan baik, guru menguasai strategi pembelajaran, dan melaksanakan evaluasi pembelajaran. Walau pun demikian, persentase ketercapaian kinerja guru belumlah mencapai $100 \%$. Berdasarkan hasil wawancara hal ini mungkin disebabkan karena kurang tersedianya media pembelajaran yang mendukung seperti $\mathrm{OHP}, \mathrm{M}$-fokus dan sebagainya. Selain itu masih kurangnya perhatian dari pemerintah daerah dalam hal ini dinas pendidikan setempat untuk mengadakan seminar atau pelatihan kepada guru. Selanjutnya, dari masing-masing variabel, akan diuraikan pengaruh dari masing-masing variabel independen $(X 1, X 2$, dan $X 3)$ terhadap variabel dependen $(\mathrm{Y})$ baik secara sendirisendiri maupun secara bersama-sama.

Pengaruh Komunikasi Organisasi terhadap Kinerja Guru SMA di Kabupaten Maluku Tenggara.

Hasil penelitian ini secara deskriptif mengungkap komunikasi organisasi SMA di Maluku Tenggara, dimana diperoleh bahwa berdasarkan tingkat kecenderungannya, persentase responden yang termasuk dalam kategori tinggi sebesar $65,71 \%$, kategori sedang sebanyak $34,29 \%$, sedangkan kategori rendah $0 \%$. Selain itu diperoleh juga bahwa jumlah skor total komunikasi organisasi yang dicapai oleh 140 responden/guru sebesar 7030, sedangkan skor maksimal yang mungkin dicapai oleh 140 responden sebesar 8960. Persentase ketercapaian komunikasi organisasi secara keseluruhan pada SMA di Maluku Tenggara adalah sebesar $78,46 \%$. Angka ini cukup besar walau pun belum sampai $100 \%$. Disamping itu skor rata-rata komunikasi organisasi yang dicapai adalah sebesar 50,22 dan komunikasi organisasi ada pada kategori sedang.

Berdasarkan hasil deskriptif di atas secara garis besar dapat dikatakan bahwa komunikasi organisasi antar guru serta antar guru dan kepala sekolah pada SMA di Maluku Tenggara berjalan efektif. Hal 
tersebut dapat dilihat dari besarnya persentase ketercapaian komunikasi organisasi secara keseluruhan yaitu sebesar 78,46\%. Hal ini didukung dengan hasil wawancara yang menyimpulkan bahwa kepala sekolah mau mendengar usul dan saran dari guru, guru mau saling berbagi informasi, serta guru bersedia menerima kritikan yang membangun.

Selanjutnya penelitian ini mengungkap pengaruh komunikasi organisasi (X1) terhadap kinerja guru SMA di kabupaten Maluku Tenggara (Y). Hasil analisis regresi linier sederhana $\mathrm{X} 1$ terhadap $\mathrm{Y}$ menemukan koefisien korelasi $\mathrm{R}$ sebesar 0,475. Koefisien korelasi sebesar 0,475 menunjukan bahwa terdapat hubungan yang positif dengan kategori sedang antara komunikasi organisasi dengan kinerja guru. Artinya bahwa semakin naik komunikasi organisasi, kinerja guru pun naik/meningkat. Hasil analisis regresi juga menemukan koefisien adjusted $\mathrm{R}^{2}$ sebesar 0,220 . Hal ini berarti komunikasi organisasi memberikan sumbangan terhadap kinerja guru sebesar $22 \%$. Sebesar $100 \%$ - $22 \%$ dipengaruhi oleh variabel lain.

Hasil penelitian ini menunjukan bahwa komunikasi organisasi berpengaruh terhadap kinerja guru. Komunikasi yang efektif dan terbuka antar guru dan guru, guru dan kepala sekolah, guru dan siswa, serta antar setiap warga sekolah dapat mengarahkan anggota organisasi untuk menjalankan tugas dengan baik sehingga dapat berdampak positif terhadap kinerja warga sekolah dalam hal ini guru. Hasil penelitian ini sesuai dengan teori yang dipaparkan oleh Ivancevich, et al, (2007, p.115) yang menyatakan "Komunikasi membantu anggota-anggota organisasi mencapai tujuan individu dan juga tujuan organisasi, merespon dan mengimplementasikan perubahan organisasi, mengkoordinasikan aktivitas organisasi, dan ikut memainkan peran dalam hampir semua tindakan organisasi yang relevan". Dengan demikian perlu terus diupayakan agar tercipta komunikasi yang efektif, terbuka, serta komunikasi yang terarah dengan baik antara guru dengan guru, guru dengan ke- pala sekolah, guru dengan siswa, dan antar semua warga sekolah sehingga kinerja guru SMA di kabupaten Maluku Tenggara pun dapat terus ditingkatkan.

Pengaruh Iklim Organisasi terhadap Kinerja Guru SMA di Kabupaten Maluku Tenggara.

Hasil penelitian ini secara deskriptif mengungkap iklim organisasi SMA di Maluku Tenggara, dimana diperoleh bahwa berdasarkan tingkat kecenderungannya, persentase responden yang termasuk dalam kategori tinggi sebesar 37,86\%, kategori sedang sebanyak $62,14 \%$, sedangkan kategori rendah $0 \%$. Selain itu diperoleh juga bahwa jumlah skor total iklim organisasi yang dicapai oleh 140 responden/guru sebesar 14357, sedangkan skor maksimal yang mungkin dicapai oleh 140 responden sebesar 18480. Persentase ketercapaian iklim organisasi secara keseluruhan pada SMA di Maluku Tenggara adalah sebesar $77,69 \%$. Disamping itu skor rata-rata komunikasi organisasi yang dicapai adalah sebesar 102,55, dan termasuk dalam kategori sedang.

Berdasarkan hasil deskriptif di atas secara garis besar dapat dikatakan bahwa iklim organisasi pada SMA di kabupaten Maluku Tenggara tercipta secara kondusif, dimana lingkungan fisik yang cukup memadai, adanya iklim yang terbuka, iklim yang sehat dan iklim kewarganegaraan. Hal tersebut dapat dilihat dari besarnya persentase ketercapaian komunikasi organisasi secara keseluruhan yaitu sebesar $77,69 \%$. Hal ini didukung juga dari hasil wawancara yang menyimpulkan bahwa para guru merasa nyaman dalam lingkungan fisik, hubungan antar para guru serta guru dan kepala sekolah hangat dan terbuka, kepala sekolah terbuka untuk saran guru. Walau pun demikian, masih terdapat kekurangan yaitu tenaga guru, perlengkapan dan bahan ajar kelas, persediaan dan kebersihan MCK, dan pagar sekolah.

Penelitian ini mengungkap pengaruh iklim organisasi (X2) terhadap kinerja guru SMA di kabupaten Maluku Tenggara (Y). Hasil analisis regresi linier sederhana $X 2$ terhadap $\mathrm{Y}$ menemukan koefisien korelasi 
$\mathrm{R}$ sebesar 0,592. Koefisien korelasi sebesar 0,592 menunjukan terdapat hubungan yang positif dengan kategori sedang antara iklim organisasi dengan kinerja guru. Artinya, semakin naik iklim organisasi, kinerja guru pun semakin naik/meningkat. Hasil analisis regresi juga menemukan koefisien adjusted $\left(\mathrm{R}^{2}\right)$ sebesar 0,345. Hal ini berarti iklim organisasi memberi sumbangan terhadap kinerja guru sebesar $34,5 \%$.

Hasil penelitian ini menunjukan bahwa iklim organisasi berpengaruh terhadap kinerja guru. Iklim organisasi yang kondusif, dimana lingkungan fisik yang memadai, iklim yang terbuka, iklim yang sehat serta iklim kewarganegaraan yang dapat dirasakan oleh guru mampu membangkitkan/menggerakkan guru untuk meningkatkan kinerjanya. Hasil penelitian ini sesuai dengan teori yang dikemukan oleh Mulyasa (2007, p.23) menyatakan iklim sekolah yang kondusif, dimana lingkungan yang aman, nyaman dan tertib ditunjang oleh optimisme dan harapan warga sekolah, serta kesehatan sekolah dapat membuat guru untuk mengembangkan berbagai kompetensinya sehingga kinerja guru pun dapat meningkat. Seperti halnya iklim fisik, suasana kerja yang tenang dan menyenangkan juga akan membangkitkan kinerja para tenaga kependidikan (Mulyasa, 2007, p.120).

Iklim organisasi yang terbuka, sehat, dan kewarganegaraan, serta lingkungan fisik yang memadai perlu terus diupayakan, sehingga guru merasa nyaman dan aman dalam mengaktualisasikan kompetensi-kompetensinya. Dengan demikian kinerja guru pun dapat ditingkatkan.

Pengaruh Gaya Kepemimpinan Transformasional Kepala Sekolah terhadap Kinerja Guru SMA di Kabupaten Maluku Tenggara

Hasil penelitian ini secara deskriptif mengungkap gaya kepemimpinan transformasional kepala sekolah SMA di Maluku Tenggara, dimana diperoleh bahwa berdasarkan tingkat kecenderungannya, persentase responden yang termasuk dalam kategori tinggi sebesar 49,29\%, kategori sedang sebanyak $50,71 \%$, sedangkan kategori ren- dah $0 \%$ atau tidak ada sama sekali. Selain itu diperoleh juga bahwa jumlah skor total kepemimpinan kepala sekolah yang dicapai oleh 140 responden/guru sebesar 14129, sedangkan skor maksimal yang mungkin dicapai oleh 140 responden sebesar 17360. Persentase ketercapaian kepemimpinan kepala sekolah secara keseluruhan pada SMA di Maluku Tenggara adalah sebesar $81,39 \%$. Disamping itu skor rata-rata komunikasi organisasi yang dicapai adalah sebesar 100,92, dimana angka ini termasuk dalam kategori sedang.

Berdasarkan hasil deskriptif di atas secara garis besar dapat dikatakan bahwa kepemimpinan kepala sekolah SMA di kabupaten Maluku Tenggara dengan gaya kepemimpinan transformasi dapat diterima oleh guru dan mempengaruhi kinerja guru. Hal tersebut dapat dilihat dari besarnya persentase ketercapaian kepemimpinan kepala sekolah secara keseluruhan yaitu sebesar 81,39\%. Angka ini besar, hampir mendekati $100 \%$. Selain itu juga dapat dilihat dengan besarnya skor rata-rata kepemimpinan kepala sekolah yang dicapai yaitu 100,92 dimana angka tersebut hampir mendekati batas minimal kategori tinggi yaitu 101.

Hasil wawancara juga disimpulkan bahwa kepala sekolah mensosialisaikan visi dan misi sekolah, kepala sekolah bertanggung jawab dalam melaksanakan tugasnya. Selain itu kepala sekolah jujur, objektif dalam memberikan penilaian kepada guru, serta memberikan kesempatan kepada guru untuk mengembangkan diri dan kemampuannya dengan menfasilitasi guru mengikuti seminar atau pelatihan.

Penelitian ini juga mengungkap pengaruh gaya kepemimpinan transformasional kepala sekolah (X3) terhadap kinerja guru SMA di kabupaten Maluku Tenggara (Y). Hasil analisis regresi linier sederhana X3 terhadap Y menemukan koefisien korelasi R sebesar 0,706. Koefisien korelasi sebesar 0,706 menunjukan bahwa terdapat hubungan yang positif dengan kategori kuat antara kepemimpinan kepala sekolah dengan kinerja guru. Artinya bahwa semakin naik kepemimpinan kepala sekolah, kinerja 
guru pun semakin naik/meningkat. Hasil analisis regresi juga menemukan koefisien adjusted $\left(\mathrm{R}^{2}\right)$ sebesar 0,494 . Hal ini berarti kepemimpinan kepala sekolah berpengaruh terhadap kinerja guru sebesar $49,4 \%$.

Hasil penelitian ini menunjukan bahwa gaya kepemimpinan transformasional kepala sekolah berpengaruh terhadap kinerja guru. Kepemimpinan kepala sekolah dengan gaya transformasi, dimana kepala sekolah dipercaya dan diterima warga sekolah, tegas, mampu mensosialisasikan visi, misi sekolah. Selain itu kepala sekolah yang mampu memotivasi guru, melakukan supervisi, dan peduli terhadap individu guru. Dengan demikian maka, guru pun akan bersemangat untuk mengaktualisasikan kompetensi-kompetensinya sehingga kinerja guru pun dapat meningkat.

Hasil penelitian ini sesuai dengan teori yang disampaikan oleh Bass \& Riggio (2006, p.3) menyatakan bahwa para pemimpin transformasional merupakan pemimpin-pemimpin yang menstimulasi dan menginspirasi para pengikut untuk mencapai tujuan yang lebih besar, dan dalam proses kepemimpinannya mengembangkan kemampuan kepemimpinan yang dimilikinya. Pemimpin-pemimpin transformasional membantu pengikutnya untuk tumbuh dan berkembang menjadi pemimpin dengan cara menanggapi kebutuhan pengikut, memberdayakan pengikut dan mengarahkan pengikut untuk menggapai tujuan individu, pemimpin, kelompok dan organisasi. Tujuan individu, pemimpin, kelompok, dan organisasi sekolah dapat dicapai jika guru mampu berkinerja baik.

Kepemimpinan kepala sekolah dengan gaya transformasi perlu terus diupayakan oleh kepala sekolah agar guru dapat maksimal mengaktualisasikan kompetensikompetensinya. Dengan demikian maka kinerja guru pun dapat terus ditingkatkan.

Pengaruh Komunikasi Organisasi, Iklim Sekolah, dan Gaya Kepemimpinan Transformasional Kepala Sekolah terhadap Kinerja Guru SMA di Kabupaten Maluku Tenggara.

Penelitian ini mengungkapakan pengaruh komunikasi organisasi, iklim orga- nisasi, dan gaya kepemimpinan transformasional kepala sekolah secara bersamasama terhadap kinerja guru. Seperti yang telah diungkapkan dalam hasil penelitian bahwa analisis regresi linier ganda menunjukkan ada korelasi yang kuat antara komunikasi organisasi (X1), iklim organisasi (X2), gaya kepemimpinan transformasional kepala sekolah (X3) secara bersama-sama dengan kinerja guru, dimana koefisien korelasi (R) sebesar 0,775. Selain itu, koefisien adjusted $\left(\mathrm{R}^{2}\right)$ yang diperoleh sebesar 0,561. Hal ini menunjukan komunikasi organisasi (X1), iklim organisasi (X2), dan gaya kepemimpinan kepala sekolah (X3) secara bersama-sama berpengaruh terhadap kinerja guru $(\mathrm{Y})$ sebesar $56,1 \%$.

Hal ini berarti bahwa variasi variabel independen (komunikasi organisasi, iklim sekolah, dan gaya kepemimpinan kepala sekolah) yang digunakan dalam model regresi mampu menjelaskan sebesar 56,1\% variabel dependen (kinerja guru). Atau dengan kata lain dapat dikatakan bahwa naik turunnya nilai Y (kinerja guru) dapat dijelaskan oleh ketiga variabel independen (X1, X2, dan (X3) secara bersama-sama dengan persentase $56,1 \%$ melalui persamaan regresi sebagai berikut.

$Y=57,103+0,180 X 1+0,221 X 2+0,501 X 3$.

Sisanya sebesar $43,9 \%$ dipengaruhi atau dijelaskan oleh variabel lain yang tidak dimasukan dalam penelitian ini. Dengan demikian, hasil penelitian ini menunjukkan bahwa jika komunikasi organisasi sekolah dapat berjalan efektif dengan arah komunikasi yang baik, lingkungan organisasi sekolah yang mendukung, iklim sekolah yang terbuka, sehat dan kewarganegaraan dapat dirasakan guru, serta kepemimpinan kepala sekolah dengan gaya kepemimpinan transformasi, maka 56,1\% guru tersebut cenderung memiliki kinerja yang baik.

\section{Simpulan dan Saran}

Simpulan

Dari hasil perhitungan analisis data dan pembahasan dalam penelitian ini, dapat disimpulkan beberapa hal sebagai beri- 
kut: (1) komunikasi organisasi (X1) berpengaruh positif terhadap kinerja guru SMA (Y) di kabupaten Maluku Tenggara sebesar $22,0 \%$; (2) iklim organisasi (X2) berpengaruh positif terhadap kinerja guru SMA (Y) di kabupaten Maluku Tenggara sebesar $34,5 \%$; (3) gaya kepemimpinan transformasional kepala sekolah (X3) berpengaruh positif terhadap kinerja guru SMA (Y) di kabupaten Maluku Tenggara sebesar 49,4\%; (4) komunikasi organisasi (X1), iklim organisasi (X2), dan gaya kepemimpinan transformasional kepala sekolah (X3) secara bersama-sama berpengaruh positif terhadap kinerja guru SMA (Y) di kabupaten Maluku Tenggara sebesar 56,1\%.

Saran

Berdasarkan pembahasan dan kesimpulan penelitian, dapat disarankan beberapa hal sebagai berikut. Pertama, bagi kepala SMA di kabupaten Maluku Tenggara, agar kiranya menggunakan gaya kepemimpinan transformasional dan dapat berkomunikasi secara efektif dengan arah komunikasi yang baik, sehingga guru dapat mengaktualisasikan berbagai kompetensi yang dimiliki. Dengan demikian maka kinerja guru pun semakin baik/meningkat.

Kedua, bagi kepala sekolah SMA di kabupaten Maluku Tenggara, agar kiranya dapat menciptakan iklim organisasi/sekolah yang kondusif, sehingga warga sekolah teristimewa para guru dapat merasa aman dan nyaman, sehingga guru dapat berkinerja dengan baik. Ketiga, bagi para guru SMA di Maluku Tenggara, agar kiranya dapat juga berkomunikasi secara efektif baik antar guru, mau pun kepada atasan, atau pun kepada siswa.

Keempat, bagi para guru SMA di kabupaten Maluku Tenggara, agar kiranya dapat menciptakan iklim organisasi/sekolah yang kondusif, sehingga warga sekolah dan para guru sendiri dapat merasa aman dan nyaman, sehingga guru dapat berkinerja baik. Kelima, bagi Dinas Pendidikan Kabupaten Maluku Tenggara agar kiranya dapat membuat program dan melaksanakan pelatihan atau seminar kepada guru, sehingga dengan demikian dapat menambah pengetahuan guru, serta guru lebih dapat mengembangkan kompetensinya.

\section{Daftar Pustaka}

Arikunto, S. (2010). Prosedur Penelitian. Yogyakarta: Rineka Cipta

Azwar, S. (2007). Penyusunan Skala Psikologi. Yogyakarta: Pustaka Pelajar.

Bass, B.M \& R.E. Riggio. (2006). Transformasional Leadership. New York: Lawrence Erbaum Associates Publisher.

Fahmi, I. (2012). Manajemen: Teori, kasus, dan solusi. Bandung: Alfabeta.

Gibson. J.L, et al. (2009). Organizations: Behavior, structure, processes. 13thed. New York: Mc Graw-Hill.

Hoy, W.K \& Miskel, C.G. (2013). Educational administration: Theory, Research, and Practice International Eighth Edition. New York: The McGraw-Hill Companies, Inc.

Ivancevich, J. M \& Konopaske, R. \& Matteson, M. T. (2007). Perilaku dan Manajemen Organisasi. (Terjemahan Dharma Yuwono). Jakarta: Erlangga

Mathis, R. L. \& Jackson, J. H. (2006). Manajemen Sumber Daya Manusia. Edisi 10. (Terjemahan Diana Angelica). Jakarta: Salemba empat.

Mulyasa. (2013). Uji Kompetensi dan Penilaian Guru. Bandung: PT. Remaja Rosdakarya.

Republik Indonesia. (2003). Undang-Undang Nomor 20, tahun 2003, tentang sistem pendidikan nasional.

Republik Indonesia. Undang-Undang Nomor 14, tahun 2005, tentang Guru dan Dosen.

Robbins, S.P. (2006). Perilaku Organisasi. 10thed. (Terjemahan Benyamin Molan). Klaten: PT Intan Sejati.

Wirawan. (2007). Budaya dan Iklim organisasi: Teori, aplikasi, dan penelitian. Jakarta: Salemba empat. 